\title{
Is "Obamacare' suddenly on the ropes?
}

$\mathrm{U}$ nited States President Barack Obama had no sooner signed his universal health care reform into law two years ago when Republican-led states launched a legal blitz against it.

Democrats shrugged off the lawsuits as a desperate gambit by conservatives clutching at straws after losing their case on the political front.

"Obamacare," its defenders believed, was simply too big to fail. They believe that no more.

The fate of the law, easily the most substantial reshaping of American health care policy since the 1960s, is in the hands of the Supreme Court of the United States after three days of arguments that laid bare the statute's constitutional vulnerability.

It can be a fool's errand to predict rulings based on the tenor of questioning. But it was apparent that the law's linchpin - the mandate that almost everyone must get health insurance or face fines - raised eyebrows among ideologically moderate justices and drew pure hostility from the court's right.

Justices raised the spectre that the government could force people to eat broccoli, buy cell phones, spring for burial insurance or join exercise clubs if the right to impose health insurance on people were sanctioned by the court (www.supremecourt.gov/oral_arguments /argument_transcripts/11-398-Tuesday .pdf).

"Purchase insurance in this case, something else in the next case," mused Chief Justice John Roberts, a Republican-nominated jurist and crucial swing vote on the nine-member court.

No one's words were watched more closely than those of Justice Anthony Kennedy, who votes unpredictably on ideologically cleaved cases. Challenging the government's attorney, Kennedy theorized the insurance mandate may be "a step beyond what our cases have allowed" and could thus uniquely alter a citizen's relationship with government.

"Do you not have a heavy burden of

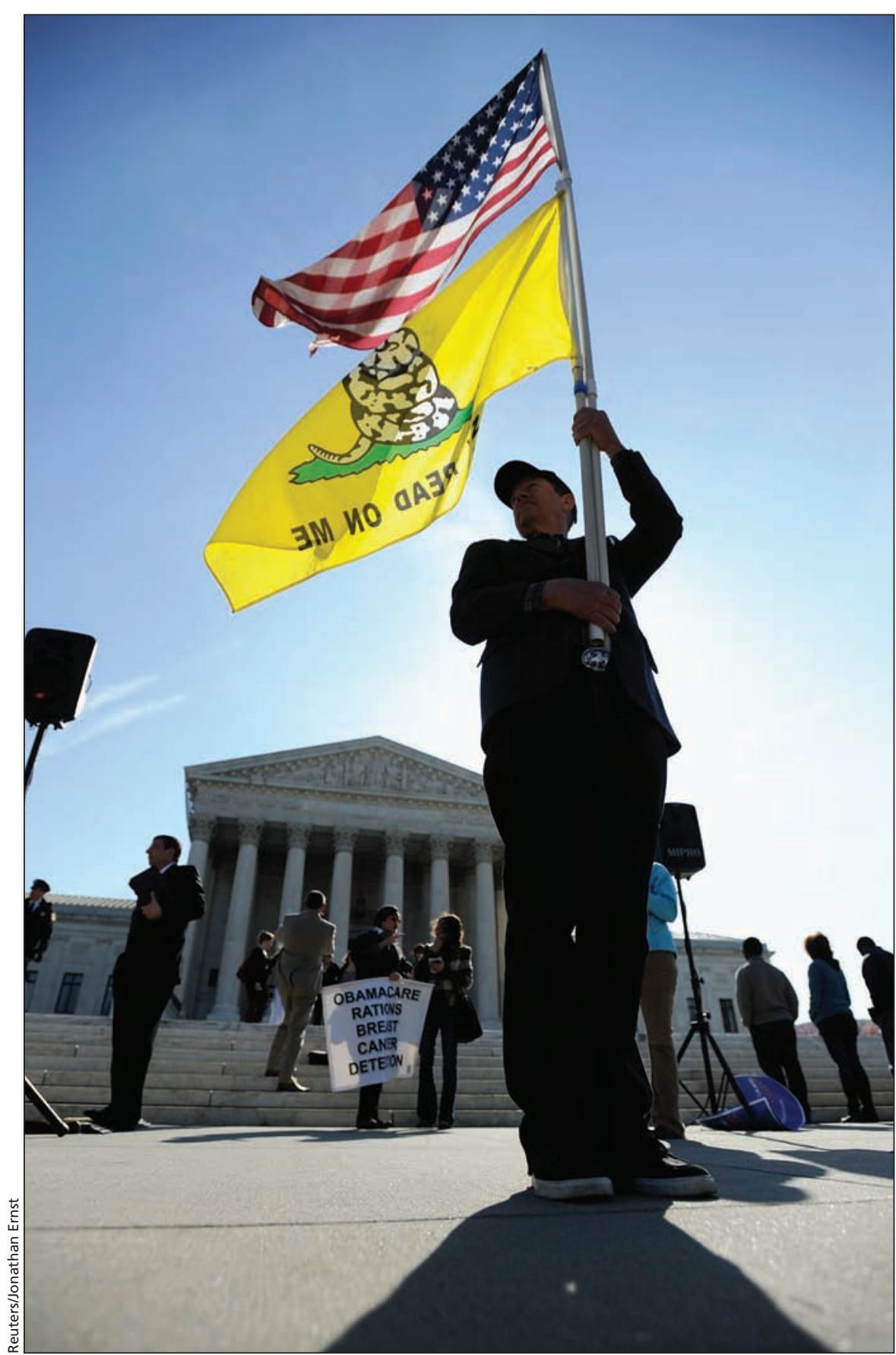

A Tea Party supporter flies his flags during the final day of legal arguments over the Patient Protection and Affordable Care Act at the Supreme Court of the United States in Washington, DC, on Mar. 28.

justification to show authorization under the Constitution?" he demanded.

The Patient Protection and Affordable Care Act, which aimed to bring more than 30 million uninsured Americans under the coverage umbrella, imposed the requirement that everyone obtain insurance in exchange for guar- 
antees that the ill cannot be denied coverage or subjected to stratospheric premiums.

While crafting the legislation, Obama reasoned early on that Americans would not swallow a single-payer system like Canada's.

Paradoxically, though, a Canadianstyle system, if politically unpalatable, might have cleared constitutional hurdles more easily. The plaintiffs argued the government's authority was limited to tax measures for such services as universal health care and the court seemed sympathetic to the proposition.

"It seems to me you're saying the only way that could be done is if the government does it itself; it can't involve the private market, it can't involve the private insurers," said liberal Justice Ruth Bader Ginsburg. "There has to be a government takeover."

Paul Clement, the attorney representing the 26 states, also argued that the government could directly subsidize the insurance industry to help it cover those who wait until they get sick to buy coverage, and recoup the cost in taxes. It may have been a somewhat disingenuous argument, given the political reality that Republi- cans are sworn to oppose any and all tax increases.

Essentially, the court must resolve two issues: whether compulsory insurance is constitutional, and if so, whether the act's other reforms must fall like a house of cards, too. That includes the law's expansion of Medicaid, the federal-state health program for the poor, to include 16 million more people. The coalition of states argued the expansion was a coercive intrusion on their jurisdiction that puts them at risk of losing health care funding for the poor.

The ruling is expected in late June and is certain to resound in the November elections, particularly as its repeal has become Republican orthodoxy, even for Mitt Romney, Obama's likely Republican presidential opponent, who as governor of Massachusetts introduced a health care overhaul featuring an individual insurance mandate that became a model for Obamacare.

Romney contends Obamacare is a breach of jurisdiction: States can require drivers to have auto or health insurance, but the federal government has no grounds to impose the same solution on the nation.

Nor is there a groundswell of sup- port for Obamacare. The primary benefits are two years off, so Americans saddled with heavy insurance costs have scant reason to rally behind the reforms.

"If this was not a political football and was just allowed to be implemented, I think most of the opposition would melt away," says Stuart Altman, professor of national health policy at Brandeis University in Massachusetts and policy advisor to Obama, as well as former US presidents Richard Nixon and Bill Clinton.

"It's a crapshoot," Altman says. "If the law is repealed, the chaos that could follow over the next five years could be substantial."

Obama rarely mentions the law. But if his signature achievement is taken down, he appears ready to resume the political fight. At a recent event in Georgia, he embraced the nickname that fierce opponents of the law use with derision. "Call it Obamacare - that's OK," he said. "Because I do care. That's why we passed it. I care about folks who were going bankrupt because they were getting sick." - Cal Woodward, Washington, DC

CMAJ 2012. DOI:10.1503/cmaj.109-4176 